\title{
PROGNOSTICATION OF PLANTATION POSSIBILITIES OF PINUS ELDARICA MEDW. BY USE OF GEOINFORMATIONAL TECHNOLOGIES
}

\author{
FARZALIYEV, $\mathrm{V}^{1^{*}}-\mathrm{AFONIN} \mathrm{A}^{2}$ \\ ${ }^{1}$ Central Botanical Garden of the NAS. Azerbaijan. Badamdar highway, 40, AZ 1073, Baku, \\ Azerbaijan Republic \\ ${ }^{2}$ Saint-Petersburg State University. Russia. St. Petersburg State University 7-9, \\ Universitetskaya nab.,St. Petersburg, 199034, Russia \\ (e-mail: biogis@yandex.ru; tel: 7(812) 465-07-51) \\ *Corresponding author \\ e-mail:v.farzaliyev@yahoo.co.uk; tel: +994-12-502-41-72; fax: +994-12-502-41-72
}

(Received $4^{\text {th }}$ Mar 2016; accepted $28^{\text {th }}$ Jun 2016)

\begin{abstract}
Eldarian Pine has high forestry potential in dry regions. Its rate of biomass accumulation rivals the fastest growing conifer species. According to this feature in this article we studied plantation possibilities to new areas on the base of the data obtained by geoinformational technologies about ecological limits of Pinus brutia var. eldarica (Medw.) Silba growing in Azerbaijan. Ecological amplitudes of this species have been defined according to the following limiting environmental factors: the sum of active temperatures above $0^{\circ} \mathrm{C}$. the annual amount of precipitation and temperature for the month of January. The obtained model previously allows to identify the possible zones of plantation and perspective territories for the cultivation of this object. It was ascertained that the Pinus brutia var. eldarica (Medw.) Silba . is characterized by a wide potentiality of plantation for its cultivation in Central Asia and Asia Minor in a number of regions of Southern Europe. Northern and Southern America and Australia.
\end{abstract}

Keywords: area, Azerbaijan, modeling, planting

\section{Introduction}

Climate-change models predict a more intense hydrological cycle with both increases in rainfall and increased length and severity of droughts (Houghton, 1997). Changes in rainfall will likely affect ecosystem processes such as primary production and nutrient release from decomposing litter caused by direct effects of altered rainfall on plants and primary decomposers, respectively. From this point of the view drought resistant plants play an important role in plantations. Extension of area of these species due to reclamation by them new territories, differed from initial ones, creates preconditions for emergence of new ecotypes and finally morphogenesis and speciation. Prognostication of possibilities of re-planting of plants to new regions is one of the main problems in plant introduction. Study of historical and present-day areas of drought resistant species makes it possible to judge their ecology and prospects of their distribution to new regions where they did not grow earlier.

Identification of potential areas of species distribution is of interest from theoretical and practical points of view. Modeling of spatial distribution of biological objects became a trend in researches and practical activities. Models of availability of habitat are good instrument of management in the field of applied biology. They can be used in development of the strategy of biodiversity conservation, plant introduction, forestry, to 
predict behavior and dynamics of species distribution under alternative effects caused, for example, by climate change (Bakkenes et.al., 2002; Pearson et al., 2002; Thuiller, 2003). Prognosis is vital for decision-making in planning, management and conservation of resources.

Modeling technologies of spatial distribution of biological objects have got a powerful impulse with appearance and development of geo-informational technologies. Geoinformational technologies and systems possess greater capabilities of reflection, analysis and modeling of geographical objects and the phenomena than traditional ways.

Among the first tasks which were set by biologists in the researchers conducted with use of the geographical information systems (GIS) there were attempts of modeling of distribution of species with use of information on the actual distribution of species and maps of environmental factors (Booth, 1990; Busby, 1991; Cadwell et al., 1996).

Symptoms of disruption of ecological equilibrium, degradation of environment and desertification of arid and semi-arid territories in Africa, Middle- and Central Asia, Australia etc. during the last half-centuries, especially after a long drought, began to appear more clearly. Centuries-old impact of a man on ecosystems of arid areas occupying about $30 \%$ of terrestrial land caused emergence and progressive growth of processes of desertification that presently gained global character (Babayev, 1995). Owing to the irrigation and flooding of these regions the possibility of their forestation arose. This ecological. social and economic problem has attracted attention of many scientists and experts of the world. In arid countries to protect the agricultural lands from water and wind erosion. crops and plantations from drought and hot dry winds it is necessary to increase the forest protective strips and planting of urbanized territories. In this case important problem is the choice of the most valuable woody and shrubby species available for cultivation in severe forest vegetation conditions. Numerous species of coniferous plants with a high economic and social potential grow in various droughty territories of the world. Both from esthetic and economic points of view pine species like: Pinus halepensis, $P$. brutia, $P$. eldarica and $P$. pinaster etc. naturally widespread in droughty territories have special significance. They successfully passed tests in various droughty areas of the world for the last 100 years. During investigations in various countries $P$. eldarica was more resistant species in comparison with others. It is connected with high adaptation possibility of the species (Safarov, 1972; Fisher and Widmoyer, 1978; Fisher, 1985; Wilson and Tran, 1995).

\section{Materials and methods}

$P$. eldarica as a Near Threatened and endemic species of the Caucasus (Farjon, 2013). The conserved plantings of $P$. eldarica are (as it is recognized by the majority of the Caucasian authors) the remains of the coastal pine forests that once bordering the coast of the Tertiary Sarmatian basin (Prilipko, 1970). In the process of its development this species has developed special properties of adaptability to adverse environmental conditions that let it to remain up to present. A number of positive biological properties of Eldarian Pine - drought tolerance, not requiring soil, wind-resistance, a certain saltresistance and adaptability to adverse environmental conditions that is developed in severe growing conditions make it irreplaceable to cultivate in areas with difficult soil and climatic conditions (Safarov, 1955).

Eldarian Pine is widely used in Southern Caucasus in planting of settlements and forestation of droughty areas with dry and even partially salted soils. It was tolerant to 
pollution as the few of the coniferous plants tolerant even in street plantings of air pollution by dust and exhausted gases. Eldarian pine is already introduced on quite considerable areas in the Caucasus, as well as in Central Asia, USA, etc. (Allegri, 1973; Eccher et al., 1982). P. eldarica successfully grows also in Tajikistan and Turkmenistan. In all research works devoted to $P$. eldarica the severe conditions of its natural growth that is developed its exclusively high drought resistance (Tutayuk, 1959; Kolesnikov and Agayev, 1961; Safarov, 1972; Eccher et. al., 1982; Reservations of the USSR, 1990; Mamedov and Halilov, 2002; Farzaliyev, 2010; Farzaliyev et al., 2010).

The purpose of the present work is ecological and geographical study of $P$. eldarica development of the model allowing to predict the perspective territories for plantation of eldarian pine.

Natural areas of Eldarian Pine growth and its planting in Transcaucasia have been observed and studied during numerous expedition researches conducted during 2008 to 2014 in the research areas (Farzaliyev, 2010). Points of growth have been registered on maps and were accessed into base; coordinates were determined by a navigator of GPS in process of development of technologies of geopositioning. Additional source of data about places of growth of elder pine were the map of the forests of Azerbaijan (1986) and the map of distribution of forest formations of Azerbaijan (Red Book, 2013).

Ecological maps for model development in the territory of Azerbaijan have been taken from the Agroatlas (Afonin et al., 2008). Layers of agroclimatic maps presented in the atlas were used: the sum of active temperatures above $0^{\circ} \mathrm{C}$, the average temperature of the coldest month (map of temperature of January for the territory of Azerbaijan was used), map of annual precipitation for the year, hydrothermal coefficient of Selyaninov for summer. At compiling up the world map of areas potentially available to introduce elder pine world climatic maps prepared by Hijmans et al. (2005) were used. Recalculation of monthly layers of temperatures to the map of active temperature above $0^{\circ} \mathrm{C}$ during vegetation period was carried out by Kelchevskaya's method (1978) using GIS Idrisi 32 (2001). In this study we are interested in ecological distribution of the specie. That is why we use only 4 ecological predictor for modeling.

Working off an ecological model of elder pine for its growth area in Azerbaijan was the first step. Ecological amplitudes of species related to environmental factors limiting its distribution were determined by extraction of values of factors in the known points of the actual growth of the species. In this purpose points of growth have been accessed into the GIS Idrisi 32 and standard procedure of extraction of data was carried out on them. After determination of ecological amplitudes of species ecologically available areas related to each limiting factor of the environment were revealed and on the basis of these maps the generalized model of growth of species was made. The model was firstly made for the territory of Azerbaijan and then used for definition of regions of the Globe available for plantations of Eldarian Pine.

Validation of the model was carried out by comparison of the known points of the actual growth of species outside of Azerbaijan with the territory predicted by the model.

In the past the pine and pine-juniper open woodland was widespread on the steppe plateau and reached Cobistan and Absheron within Transcaucasia. D. I. Sosnovsky (1910) specifies that in former times the pine went down much below on Eller Oyughu slopes. At present, the open woodland of elder pine has remained only on hard-to-reach mountain range (Fig. 2). Though height of the mountain range is rather small very difficult relief caused hard-to-reach condition and partly completely hard-to-reach condition of its separate areas. It provided preservation of elder pine in these shelters up to now. 
In more available places it was destroyed long ago by human being. Pinus brutia var. eldarica (Medw.) Silba. on the Eller Oyughu mountain range is accompanied by junipers: Juniperus rufescens Link., J. foetidissima Willd. and the juniper most widespread on the mountain range - J. polycarpos $\mathrm{C}$. Koch that together with the $P$. eldarica forms a typical arid light forest (Kolesnikov and Agayev, 1961). 406 species relating to 56 families and 195 genera (Baghyrova, 2009) were revealed in the reservation area and in surrounding agroecosystems.

The annual precipitation doesn't exceed $250 \mathrm{~mm}$ here; at the same time a precipitations drop out unevenly mainly in the early spring and late fall; number of days with a precipitation is 70; average relative humidity of air is 58\%; average overcast is 53. Annual mean temperature is $12.9{ }^{\circ} \mathrm{C}$; the sum of effective temperature for the whole vegetative period is about $3680^{\circ} \mathrm{C}$; evaporation is $727 \mathrm{~mm}$; number of days with a snow cover is 22 .

General indicator of soil samples is the high alkalinity, indicating the richness of the soil carbonate layers. Eldarian Pine substrate is a thick layer of conchoidal limestone covering the Sarmatian sandstones. Texture of the soil humus-carbonate and sandy. General index of soil tests is the high alkalinity that testify to richness of the soil by carbonate layers. A powerful layer of blistered limestone serves as substratum of elder pine covering Sarmatian sandstones. Mechanical structure of the soil is hummus and carbonate and sandy.

According to geological structure the mountain range in the most high-altitude parts is covered with elder pine suite of Aghjagyl Stage that in proportion of relief lowering is replaced by the upper Sarmatian. The upper Sarmatian is gray, bluish and greenish gray and brown clays with layers of brown coal and plaster alternating with packages of gray middleand coarse-grained carbonate sandstones. Except sandstones frequent pro-layers of shell limestone occur here. In the upper and middle parts of northern slope of the mountain range sandstones and shell rocks come to a surface being a substratum on which $P$. eldarica grows. Thanks to remarkable biological properties $P$. eldarica as irreplaceable coniferous genus has got wider prospects at cultivation in dry subtropical areas.

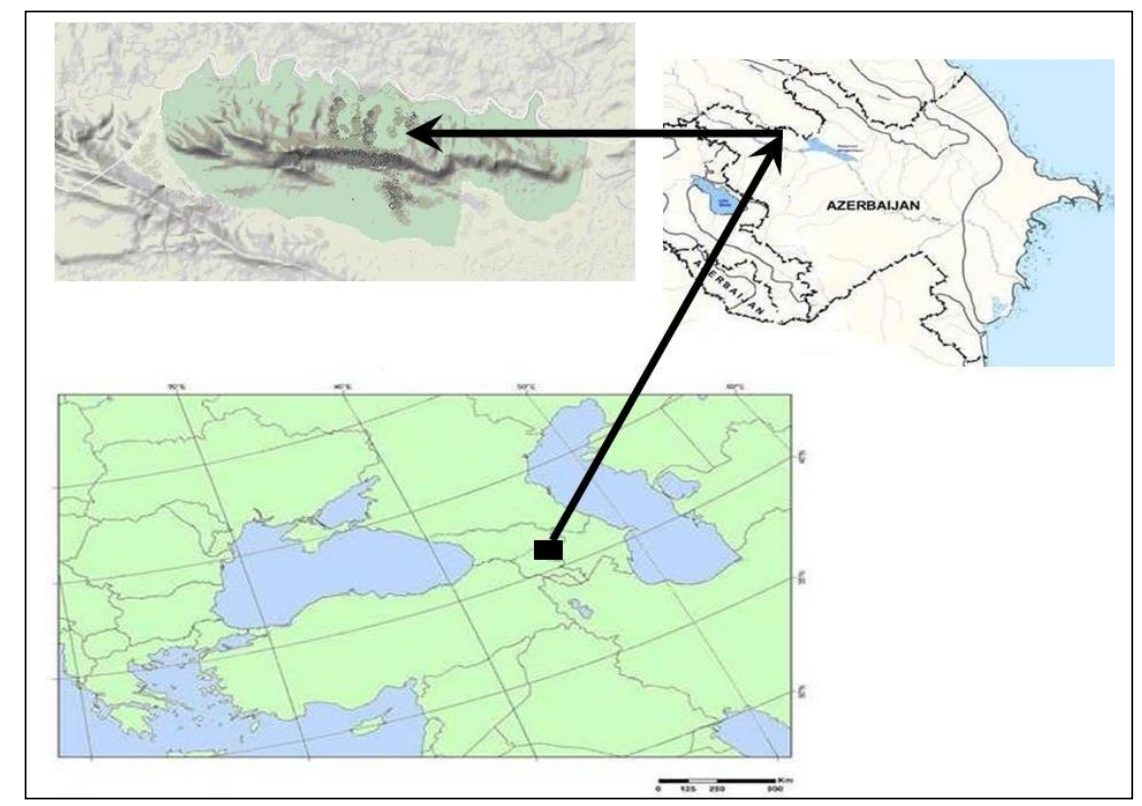

Figure 1. State Natural Preservation's map of Pinus brutia var. eldarica (Medw.) Silba 

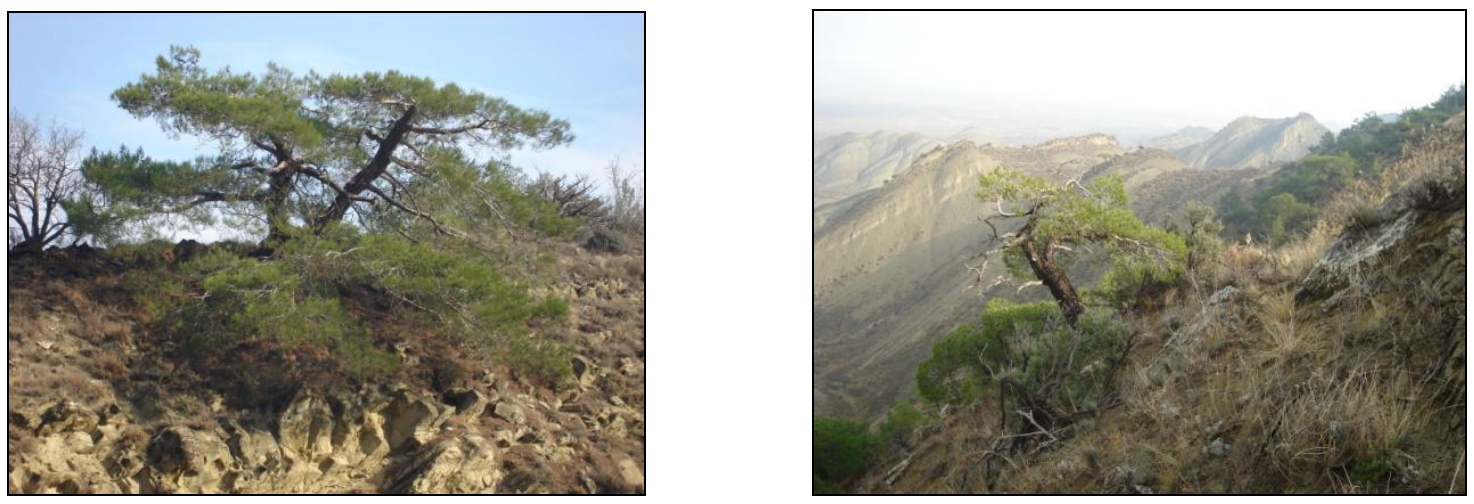

Figure 2. Characteristic places of natural area of Pinus eldarica

The major factors limiting distribution of $P$. eldarica are sum of active temperatures during vegetative period, low winter temperatures and sum of precipitation in a year. Active vegetation period of elder pine begins with transition of average air temperatures through $10^{\circ} \mathrm{C}$. The minimum sum of active temperatures (effective heat unit) necessary for passing of a seasonal cycle of ontogenesis from spring growth up to formation of seeds and preparation of plants for winter is $4500^{\circ} \mathrm{C}$.

$P$. eldarica is not frost-resistant and can be easily damaged by low winter temperatures. It sustains single temperature falls up to $-22^{\circ} \mathrm{C}$ but as the actual border of its distribution according to this factor the isometric line of January temperatures serves $-3.5^{\circ} \mathrm{C}$ in Azerbaijan.

Sufficient moistening is necessary condition for growth of plants. In this regard $P$. eldarica is very undemanding and capable to grow at $250 \mathrm{~mm}$ of precipitation per year. In condition of additional artificial irrigation of young plants and periodic watering $P$. eldarica is capable to grow in areas with the annual sum of precipitation of $200 \mathrm{~mm}$ in Absheron.

The further assessment of predicativity of ecological model showed need of an additional factor registration - seasonality of a precipitation. P. eldarica both relatives and related to it types of Pinus brutia and P. halepensis according to ecological requirements grew only in the territories being characterized existence of the droughty period in summer months abroad. Apparently it is also associated with the possibility of withdrawal from competitive pine species. The factor of seasonality of moistening was considered by inclusion into the model of additional condition: Selyaninov's hydrothermal coefficient (HTC) for summer months shouldn't exceed 0.85 .

In accordance with the above mentioned as ecological limits of growth of $P$. eldarica. According to the main limiting factors of the environment limiting its distribution were chosen: the sum of active temperature above $10^{\circ} \mathrm{C}$ from $4500^{\circ} \mathrm{C}$ to $7000^{\circ} \mathrm{C}$, the annual precipitation were 270 to $1000 \mathrm{~mm}$; temperature for January was >$3.5^{\circ} \mathrm{C}$; HTC during summer was not higher than 0.85 . The obtained data on ecological limits and existence of ecological maps allowed to carry out modeling of an area of possible distribution of Eldarian Pine. 


\section{Results and Discussion}

The presented model was used for compiling the prognostication map of world territories that are perspective from the point of view of an plantation of $P$. eldarica. Similar model calculations were carried out with use of the ecological maps made by Hijmans et al. (2005). Thus for the northern and southern hemisphere calculations of ecologically available areas according to temperatures of the coldest month counted separately: for the northern hemisphere according to January temperatures and southern - according to July. The final map united according to the mask in GIS Idrisi 32. Validation of the world prognostic map of territories, optimal for an introduction of $P$. eldarica was carried out by use of world data on known points of a successful plantation of eldarian pine.

According to ecological maps areas ecologically available for growth of Eldarian Pine per each of 3 major limiting factors of the environment were allocated. As a total prognostication area of distribution was considered the area available for growth of Eldarian Pine according to set of all the considered factors. White dots show the actual places of growth of $P$. eldarica Medw. in Azerbaijan.

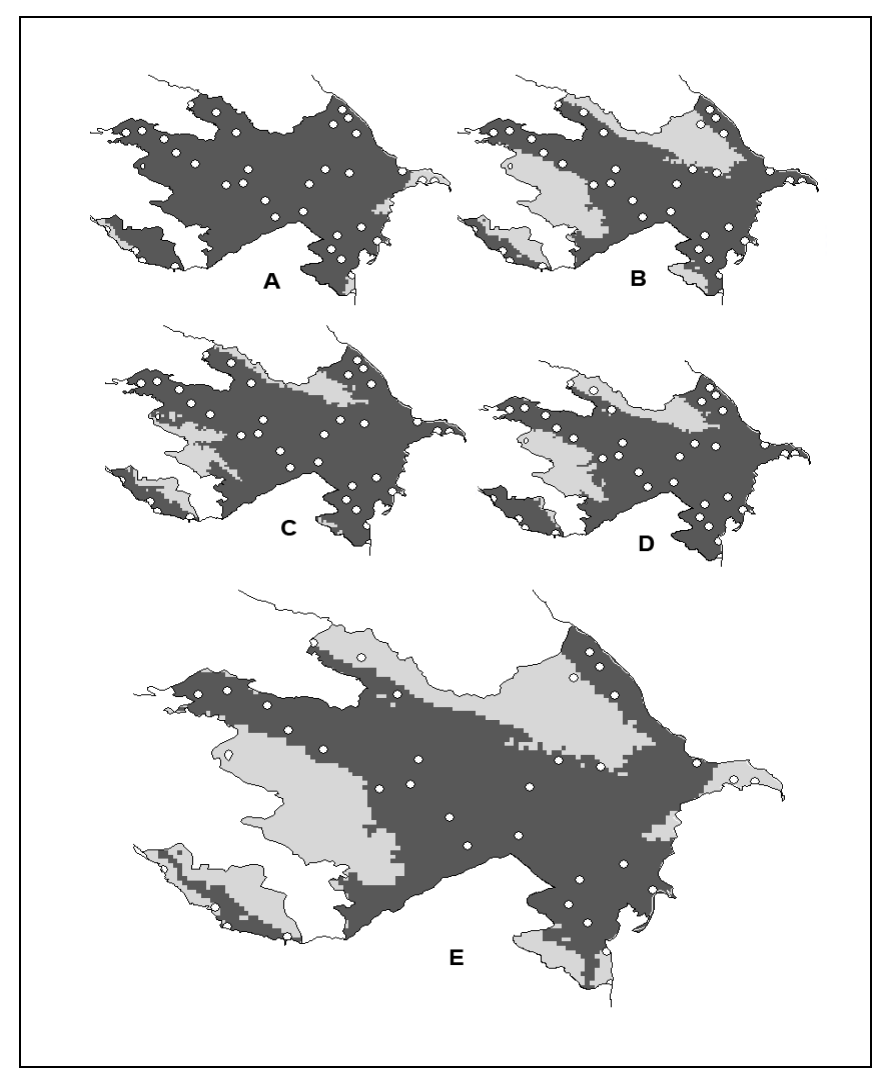

Figure 3. Ecological - geographical model of distribution of Pinus brutia var. eldarica (Medw.) Silba in Azerbaijan: A) the area ecologically available for growth of Pinus brutia var. eldarica (Medw.) Silba . according to the temperatures of the coldest month (above $-3.5^{\circ} \mathrm{C}$ ); B) on sum of active temperature above $0^{\circ} \mathrm{C}$ in vegetation period $\left(4500^{\circ} \mathrm{C}\right.$ to $\left.\left.7000^{\circ} \mathrm{C}\right) ; \mathrm{C}\right)$ on amount of precipitation for year from $270 \mathrm{~mm}$ to $1000 \mathrm{~mm} ; \mathrm{D}$ ) on the HTC for the summer period (not higher than 0.85); E) ecologically available territory on all set of the considered factors of the environment. 
Comparison of the model area with known points of a successful plantation of plants show that territories ecologically available for plantations of Eldarian Pine according to ecological model substantially coincide with the actual places of successful growth of the introduced plants (Fig. 4., 5).

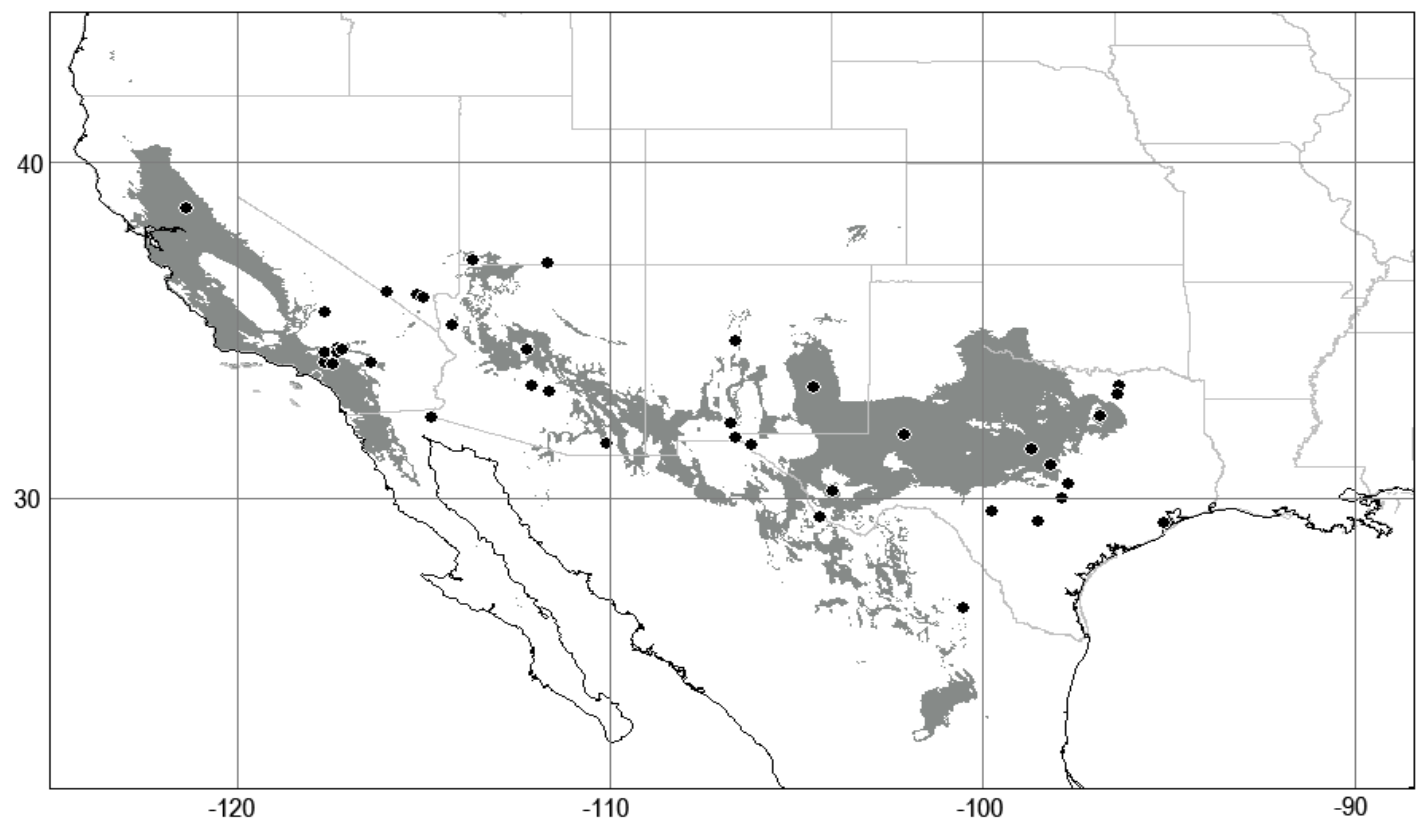

Figure 4. Comparison of predicted ecologically suitable areas with places of the actual growth of P. eldarica in North America.

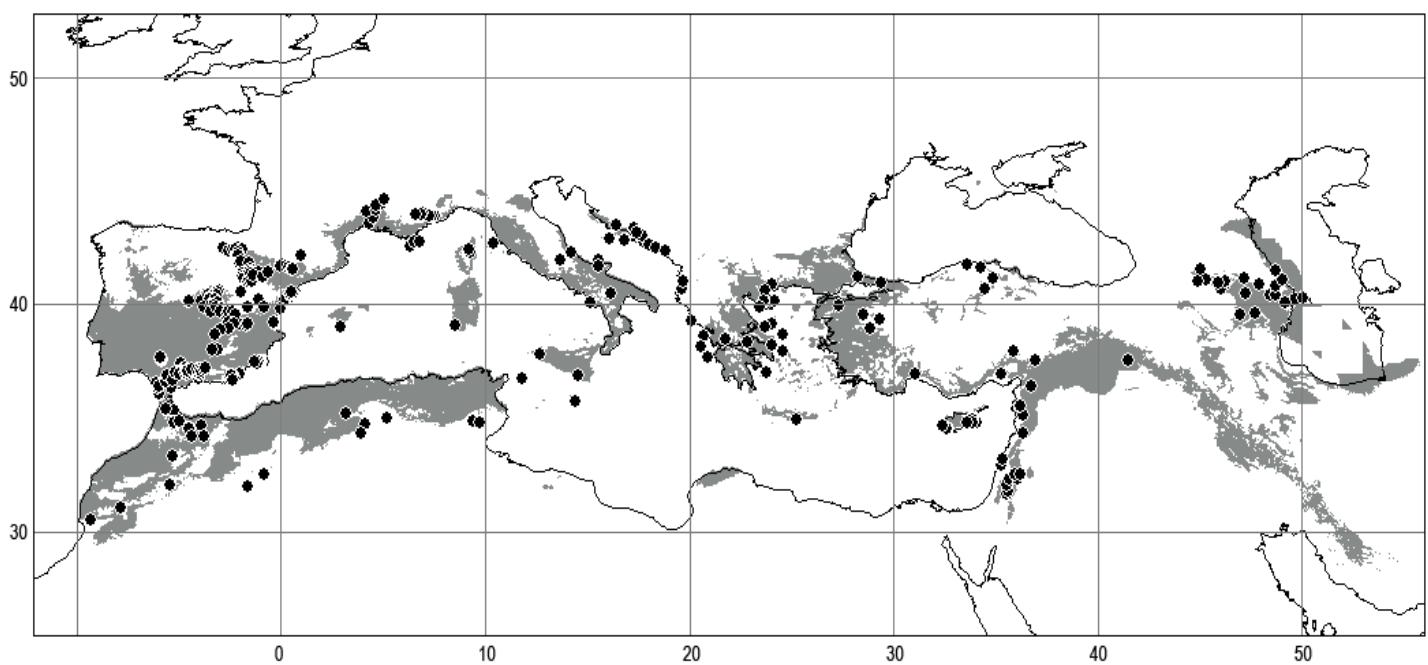

Figure 5. Comparison of predicted ecologically available territories with places of the actual growth of Pinus eldarica (Medw.) and related to it species of Pinus brutia and P. halepensis in Europe. Front Asia and North Africa. 
Dark colour showed ecologically suitable areas. black dots - known places of growth of eldarian pine. It should be noted that the known places of growth of P. eldarica in North America as a whole are dated for massifs of the territories prognosticated by the model. Some origins of the known points of growth out of the frames of the modeled area particularly can be explained by regional features of places of cultivation of $P$. eldarica - redistribution of environmental factors not considered on small-scale ecological maps. More careful acquaintance to features of cultivation of elder pine in the south of the United States showed that in some cases possibility of cultivation of $P$. eldarica outside of ecologically available territory is caused by agrotechnical features; for example use of intensive watering. It has been also ascertained that the introduced pine grows in a number of places but it experiences considerable difficulties. In particular in noted on the map in Fig. 4 four points of growth of pine in the southern Texas, going beyond ecologically available zone, grown-up plants experience considerable difficulties because of the raised humidity of climate. It is observed that pines not bad get accustomed but in the course of years the needles connected apparently with diseases of root system become brownish on them.

The total predicative map of potential of $P$. eldarica Medw. for replanting along with new territories of the Globe is given in Fig. 6. Good coincidence of ecological model to known places of the actual growth of P. eldarica Medw. and related to it types testifies to universality of the developed model and its predicative value for drawing up plans of plantation of $P$. eldarica Medw. and to far distant regions.

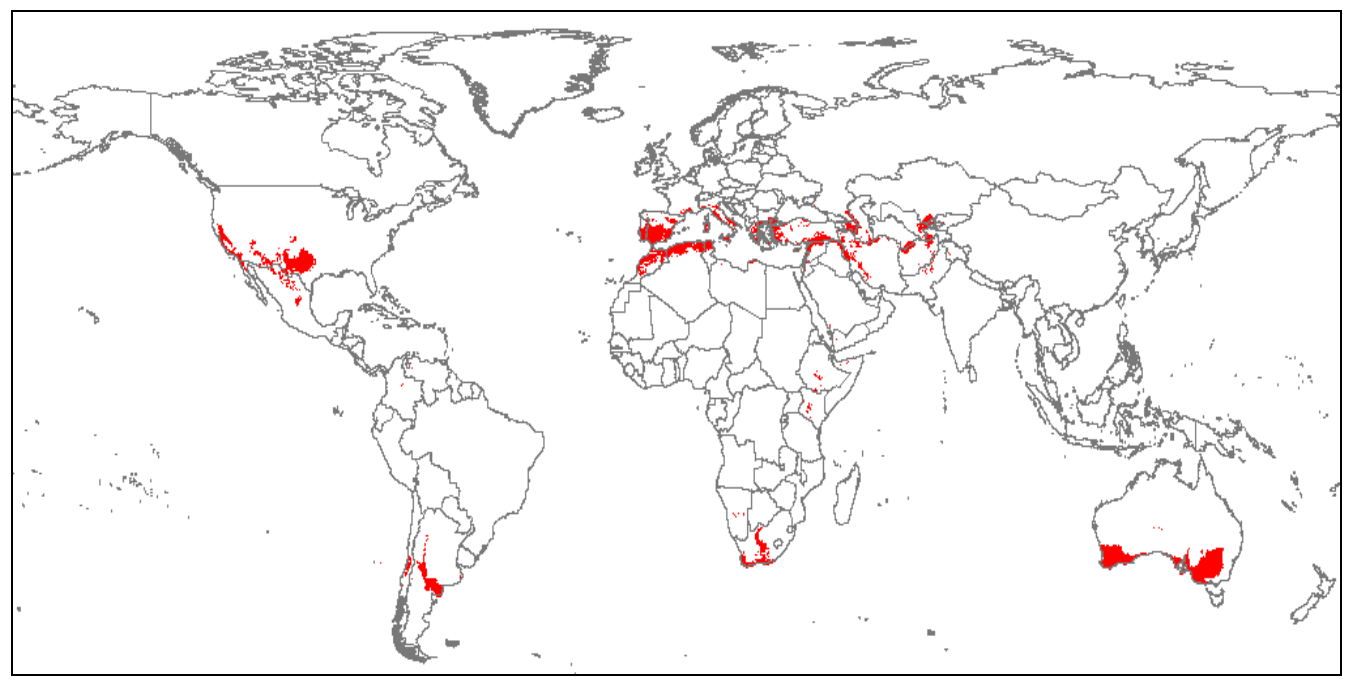

Figure 6. Globe territories ecologically available for plantation of Pinus brutia var. eldarica (Medw.) Silba . according to the data of ecological model.

Thus territories ecologically available for growth of $P$. eldarica Medw. and perspective from the introduction point of view have been determined. As a result of the researches conducted by the GIS it has been revealed that conditions for the plantation of $P$. eldarica Medw. in the Globe are quite extensive. The P. eldarica Medw. is characterized by wide plantation potential for cultivation in Central Asia and Asia Minor, in a number of regions of Southern Europe, Northern and Southern America and Australia. 


\section{Conclusion}

Distribution of plants along with land surface depends on biological features and ecological properties of plants, their ability to replanting. It depends also on ecological and biological barriers like: mountains. seas - on climate, other living organisms and human beings. Human being is able to transfer species through ecological barriers to places potentially available for their habitation, expanding the areas of growth of valuable species. reducing the risk of disappearing of Near Threatened species.

Ecological and geographical methods allow specifying places potentially available for growth of introduced species that makes such activity more effective.

\section{REFERENCES}

[1] Afonin, A., Greene, S.L. (1999): Shaping germplasm collections using modern geographic information technologies: directions being explored by the N.I. Vavilov Institute of Plant Industry, pp. 75-85 In: S.L. Greene and L.Guarino (ed): Linking Genetics and Geography: emerging strategies for conserving crop biodiversity" CSSA Special Publication no. 27. Chapter 6. , Madison, WI

[2] Afonin, A.N., Green, S.L., Dziubenko, N.I., Frolov, A.N. (eds.) Interactive Agricultural Ecological Atlas of Russia and Neighboring Countries Economic Plants and their Diseases. Pests and Weeds [Internet version 2.0]. 2008 http://www.agroatlas.ru

[3] Allegri, E. (1973): Contributo alla conoscenza del Pinus brutia Ten. [Notes on Pinus brutia] Annali del' Instituto Sperimentale per la Selvicotura Arezzo 4: 141 (translated from Italian).

[4] Bagirova, A.Kh. (2009): Flora of the Eldar shamy State Nature Reserve and its dynamics. Materials of the Int. scientific conference devoted to the 75 anniversary of the Central Botanical Garden of the Azerbaijan NAS. Baku. September 23-24. 2009. the II part. page 256-25.

[5] Babayev, A.G. (1995): Problems of developing of deserts. - Ashkhabat. Ylym. № 1. page 235

[6] Bakkenes, M., Alkemade, J.R.M., Ihle, F., Leemans, R., Latour, B. (2002): Assessing effects of forecasted climate change on the diversity and distribution of European higher plants for 2050. - Glob. Change Biol. 8: 390-407.

[7] Booth, T.H. (1990): Mapping regions climatically suitable for particular tree species at the global scale. - Forest Ecology and Management 36: 47-60.

[8] Busby, J.R. (1991): BIOCLIM - a bioclimatic analysis and prediction system. In: Margules, C.R., Austin, M.P. (eds) Nature Conservation: Cost Effective Biological Surveys and data Analysis. CSIRO, Melbourne, Pp. 64-68.

[9] Cadwell, L. L., Downs, J. L., Phelps, C. M., Nugent, J. J., Marsh, L., Fitzner, L. (1995): Sagebrush restoration in the shrub-steppe of south-central Washington in Proceedings: Shrubland ecosystem dynamics in a changing environment. Las Cruces. NM. 23-25 May 1995. Intermountain-Research-Station. USDA Forest Service. General Technical Report No. INT- GTR-338. pp 143-145

[10] Carpenter, G., Gillison, A.N., Winter, J. (1993): DOMAIN: a flexible modelling procedure for mapping potential distributions of plants and animals. Biodiversity and Conservation 2(6): 667-680.

[11] Eccher, A., Fusaro, E., Righi, F. (1982): Primi risultati di prove a dimora sui pini 
mediterranei della 'Sezione halepensis' con particolare riferimento a Pinus elder ica (Medw.) Cellulosa Carta 33: 3-30.

[12] Farzaliyev, V.S., Seyfullayev, F.S., Quliyev, I.T. (2010): Specific features of natura distribution of Eldarian Pine in the Eldarian Pine State Nature Reserve. "Climate Change \& Dendrochronology in Caspian Ecosystems" 20-21 May 2008. Caspian Ecosystems Research Institute. Sari. I.R. Iran.

[13] Farzaliyev, V. (2010): Natural regeneration of Pinus eldarica (Medw). in nature of Azerbaijan. [In Turkish]. - Proceedings of the "3rd National Forestry Congress of Black Sea". May. 20 - 22 2010. Artvin. Proceedings Book 3: 927930.

[14] Farjon, A. (2013): Pinus brutia var. eldarica. The IUCN Red List of Threatened Species 2013: e.T34183A2849651

[15] Fisher, J.T. (1985): The forestry potential of Pinus eldarica plantations. - In: Proceedings Afghan Pine and Christmas Tree Symposium. pp. 7-17.

[16] Fisher, J.T., Widmoyer, F.B. (1978): Afghan pine (Pinus brutia var. eldarica): a Potential shelterbelt species for the southern Great Plains. - In: Great Plains Agricultural Council. Proceedings - Thirteenth Annual Meeting. Oklahoma. Publication 87. pp. 104-109.

[17] Hijmans, R.J., Cameron, S.E., Parra, J.L., Jones, P.G., Jarvis, A. (2005): Very high resolution interpolated climate surfaces for global land areas. International Journal of Climatology 25: 1965-1978.

[18] Houghton, J.T. (1997): Global Warming: The Complete Briefing. - Cambridge UnivPress, Cambridge, UK.

[19] Idrisi 32 release 2. Guide to GIS and Image Processing. Volume 1-2. 2001. J. Ronald Eastman

[20] Johnston, C. A. (1998): Geographic information systems in ecology. Methods in Ecology Series. Blackwell Science. Malden. MA. 239 p.

[21] Jones, P. G., Galwey, N., Beebe, S. E., Tohme, J. (1997): The use of geographical information systems in biodiversity exploration and conservation. Biodiversity Conservation 6: 947-958.

[22] Kolesnikov, A.I., Agayev, G. (1961): Conditions of growth and natural renewal of Pinus eldarica Medw.in the homeland. Works of Research Forest Experimental Base of «ABLOS». Sukhumi. page 75-112. Ylym. № 1. page 235.

[23] Krugman, S.L. (1979): A note on Pinus eldarica (Pinus brutia var. eldarica) the so-called Mondell pine. - Revue Forestiere Francaise 31: 401-403.

[24] Mamedov, G.Sh., Khalilov, M.Y. (2002): Forests of Azerbaijan. Baku: 'Elm'. page 216-220.

[25] Mast, J. N., Veblen, T. T., Hodgson, M. E. (1997): Tree invasion within a pine/grassland ecotone: an approach with historic aerial photography and GIS modeling. - Forest Ecology and Management 93:181-194.

[26] Menon, S., Bawa, K. S. (1997): Applications of geographic information systems. remote- sensing. and a landscape ecology approach to biodiversity conservation in the Western Ghats. - Current Science 73:134-145.

[27] Pearson, R.G., Dawson, T.P., Berry, P.M., Harrison, P.A. (1995): SPECIES: a spatial evaluation of climate impact on the envelope of species. - Ecol. Model. 154: 289-300.

[28] Peterson, A.T., Ortega-Huerta, M.A., Bartley, J., Sanchez-Cordero, V., Soberon, J., Buddemeier, R.H., Stockwell, D.R.B. (2002): Future projections for 
Mexican faunas under global climate scenarios. - Nature 416: 626-629.

[29] Prilipko, L.I. (1970): Vegetation cover of Azerbaijan. Publ/house. "Elm". Pages 121-122.

[30] Red book of the Republic of Azerbaijan. (2013) Second edition. 666 p.

[31] Safarov, I.S. (1955): Pinus eldarica Medw. as species of dry subtropics. Publ/house "AS of the Azerbaijan SSR". Baku. 52 pages.

[32] Safarov, I.S. (1972): Pinus eldarica Medw. and its cultivation in the southern regions of the USSR. Baku: 'Elm'. 93 pages.

[33] Sosnovsky, D. I. (1910): Pinus eldarica Medw. "Messenger of the Tiflis Botanical Garden". issue 18 . Tiflis.

[34] Sperduto, M. B., Congalton, R. G. (1996): Predicting rare orchid (small whorled pogonia) habitat using GIS. - Photogrammetric Engineering and Remote Sensing 62:1269-1279.

[35] Thuiller, W. (1995): BIOMOD: optimizing predictions of species distributions and projecting potential future shifts under climate change. - Glob. Change Biol. 9: 1353-1362.

[36] Tutayuk, V. H. (1959): About some indices of fitness of wild-growing Pinus eldarica Medw. - Botany Journal № 2. pages 185-193.

[37] Wilson, S.M., Tran. Y.D. (1995): Trees on farms. - In: Farm Surveys Report. ABARE Canberra. pp. 83-85. 